\title{
PERILAKU MASYARAKAT TERHADAP PELAKSANAAN ARISAN \\ LELANG DALAM PERSPEKTIF EKONOMI ISLAM \\ (Studi Kasus Masyarakat Desa Paomacang Luwu Utara)
}

\section{Oleh:}

Rahmawati Muin dan Hadi

Fakultas Ekonomi dan Bisnis Islam

Universitas Islam Negeri Alauddin Makassar

rahmawati.ekis@gmail.com dan sirajuddinroy@gmail.com

\begin{abstract}
ABSTRAK
Penelitian ini bertujuan untuk mengetahui motivasi masyarakat ikut serta dalam pelaksanaan kegiatan arisan lelang berdasarkan pandangan ekonomi Islam. Hasil penelitian ini diharapkan dapat menjadi sumber informasi bagi masyarakat dalam rangka meningkatkan pengetahuan mengenai arisan uang dengan sistem lelang. Metode yang digunakan dalam penelitian adalah metode penelitian kualitatif dengan pendekatan deskriptif. Sumber data penelitian berasal dari sumber data primer dan sekunder. Teknik pengumpulan data dengan menggunakan metode trianggulasi. Hasil dari penelitian menunjukkan bahwa motivasi masyarakat ikut serta dalam kegiatan arisan uang dengan sistem lelang adalah sebagai salah satu tempat menabung dan untuk mendapatkannya sangatlah mudah. Namun dalam pandangan ekonomi Islam arisan lelang ini terdapat unsur-unsur yang dilarang dalam melakukan transaksi muamalah yaitu unsur riba, gharar, dan maisir serta terdapat unsur ketidakadilan atau ketidakseimbangan yang tidak sesuai dalam prinsip dasar ekonomi Islam.
\end{abstract}

Kata kunci: Motivasi; Arisan; Lelang. 


\section{PENDAHULUAN}

Manusia sebagai makhluk ciptaan Allah Swt. adalah makhluk sosial, maksudnya manusia tidak bisa berdiri sendiri tanpa berinteraksi dengan orang lain yang kemudian disebut dengan hidup bermasyarakat. Salah satu hubungan interaksi antar sesama manusia dapat dijumpai dalam kegiatan ekonomi atau bermuamalah. ${ }^{1}$ Kegiatan ekonomi atau muamalah merupakan kegiatan transaksi harta benda yang dilakukan manusia berdasarkan ketentuan-ketentuan umum yang ada dalam syara' seperti larangan riba, gharar, dan maysir. ${ }^{2}$

Seiring perkembangan zaman, kegiatan muamalah di dalam masyarakat telah mengalami perkembangan yang sangat pesat. Hal ini dilatarbelakangi dengan adanya pola pikir masyarakat serta adat kebiasaan yang berbeda. Salah satu bentuk kegiatan muamalah yang dilakukan sebagian masyarakat di Indonesia adalah arisan. Arisan merupakan bagian dari muamalah yang terjadi di berbagai daerah. Sampai saat ini telah menjadi kegiatan sebagian kelompok masyarakat,misalnya di instansi pemerintah, perusahaan, rukun tetangga, sekolah bahkan tempat ibadah yang dilakukan secara turun temurun.

Arisan lelang dalam pelaksanaannya para anggota melakukan lelang sebelum diumumkan pemenang dalam arisan tersebut sebagaimana diketahui bahwa lelang merupakan penjualan barang didepan banyak orang dengan adanya penawaran secara terbuka dan yang berhak mendapatkan barang tersebut adalah yang paling tinggi penawarannya. Dengan ini, yang menjadi pemenang dalam arisan lelang adalah anggota yang memiliki harga penawaran atau lelangan tertinggi namun lelang yang dipakai adalah lelang tertutup, dan harga penawaran tersebut dijadikan potongan biaya iuran anggota arisan

${ }^{1}$ Masduha Abdurrahman, Pengantar dan Asas-asas Hukum Perdata Islam "Fiqh Muamalah", cet. Ke-1, (Surabaya: Central Media,1992), h. 74.

${ }^{2}$ Muhammad, Lembaga-lembaga Keuangan Umat Kontemporer, (Yogyakarta: UII Press,2000), h. 2. 
lainnya karena sistem lelang dijadikan sebagai tingkat kerugian bagi pemenang dalam arisan.

Salah satu kegiatan arisan terdapat di Desa Paomacang Kecamatan Sukamaju Kabupaten Luwu Utara yaitu Arisan Lelang atau biasa disebut dengan arisan tembak yang sudah menjadi tradisi masyarakat setempat. Arisan lelang atau arisan tembak ini pada mulanya dilakukan untuk memenuhi kebutuhan yang mendesak secara bergantian oleh anggota arisan. Misalnya ada keluarga anggota arisan yang mengalami musibah atau keperluan lainnya yang sangat mendesak dan berhubungan dengan uang, maka anggota arisan tersebut diberi kesempatan untuk mendapatkan undian secepatnya dengan resiko adanya pengurangan jumlah uang yang didapatkan.

Namun jika lelang dilakukan hanya untuk mendapatkan arisan secara cepat tanpa memikirkan besarnya tingkat kerugian yang harus ditanggung, maka seringkali para anggota melakukan persaingan harga yang relatif tinggi dengan unsur kesengajaan. Karena besarnya tingkat kerugian tergantung berapa banyak anggota yang ikut serta dalam proses lelang, semakin banyak anggota yang melakukan lelang maka semakin kecil pula kemungkinan untuk mendapatkan arisan. Maka para anggota tidak tanggung-tanggung melakukan lelang dengan harga yang tinggi agar dapat memenangkan arisan tersebut. Dalam hal ini sering terjadi perilaku negatif yang akhirnya menjadi kebiasaan masyarakat setempat. Hal ini tentu tidak sesuai dengan prinsip ekonomi Islam.

Ekonomi Islam adalah pengetahuan dan aplikasi dari anjuran dan aturan syariah yang mencegah ketidakadilan dalam memperoleh sumber-sumber daya materiel sehingga tercipta kepuasan manusia dan memungkinkan mereka menjalankan perintah Allah dan mengikuti aturan masyarakat. ${ }^{3}$ Dari beberapa pendapat mengenai ekonomi Islam bahwa setiap perilaku manusia khususnya dalam kegiatan ekonomi yang berhubungan dengana pemenuhan kebutuhan harus sesuai dengan aturan syariah dan aturan dalam bermasyarakat. Islam 
mendorong umatnya untuk mencari nafkah dengan jalan yang sesuai dengan syariat sebagaimana dalam Al-Qur'an Allah berfirman dalam QS. AlBaqarah/2:188:

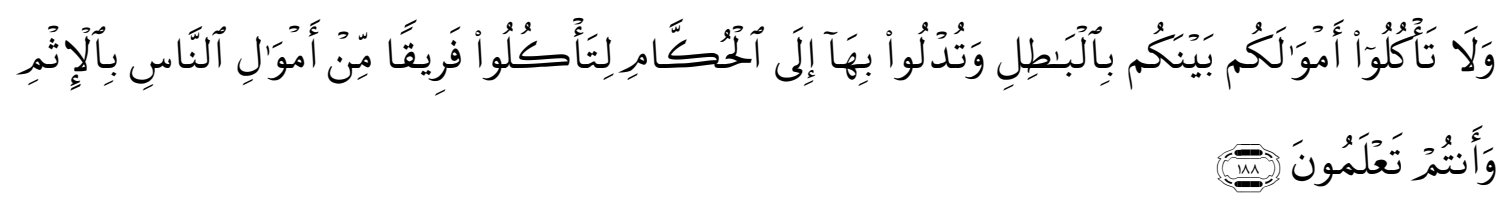

Terjemahnya:

Dan janganlah sebagian kamu memakan harta sebagian dari yang lain diantara kamu dengan jalan yang batil dan (janganlah) kamu membawa (urusan) harta itu kepada hakim, supaya kamu dapat memakan sebahagian daripada harta benda orang lain itu dengan (jalan berbuat) dosa, padahal kamu mengetahui. ${ }^{4}$

Ayat ini menjelaskan bahwa dalam mencari nafkah dan rezeki haruslah dengan menempuh cara yang halal dan sesuai dengan aturan syariah yang telah diatur dalam al-Qur'an dan Sunnah dan aturan dalam bermasyarakat, agar mendapatkan keberkahan didalamnya. Allah melarang umatnya mencari nafkah dengan jalan yang batil termasuk intimidasi, eksploitasi, dan paksaan karena merupakan perbuatan yang tidak baik dan merugikan. Sehingga untuk mencapai tujuan dalam mencari rezeki adalah mencari yang paling berkah, bukan mencari manakah yang menghasilkan paling banyak. Karena penghasilan yang banyak belum tentu berkah.

${ }^{4}$ Departemen Agama, Al-Qur'an dan Terjemahannya, (Jakarta: PT. Insan Media Pustaka, 2013), h. 29. 


\section{TINJAUAN TEORITIS}

\section{Perilaku}

Perilaku adalah tindakan atau aktivitas dari manusia itu sendiri yang mempunyai arti yang sangat luas antara lain: berjalan, berbicara, menangis, tertawa, bekerja, kuliah, menulis, membaca, dan sebagainya. Perilaku dalam kamus besar bahasa Indonesia adalah tanggapan atau reaksi individu terhadap rangsangan atau lingkungan. ${ }^{5}$

\section{Masyarakat}

Masyarakat berasal dari kata Arab Musyarak yang bermakna ikut serta, berpartisipasi atau masyarakat yang berarti bergaul, dalam bahasa Inggris masyarakat disebut dengan society yang berarti sekumpulan orang yang membentuk sebuah sistem dan terjadi komunikasi di dalamnya. ${ }^{6}$ Menurut Kamus Besar Bahasa Indonesia masyarakat adalah sejumlah manusia dalam arti seluas-luasnya dan terikat oleh suatu kebudayaan yang mereka anggap sama. ${ }^{7}$

\section{Motivasi}

Motivasi berasal dari bahasa Latin yang berbunyi movere yang berarti dorongan atau menggerakkan. ${ }^{8}$ Motivasi adalah aktivitas perilaku yang bekerja dalam usaha memenuhi kebutuhan-kebutuhan yang diinginkan. Motivasi dalam Islam diartikan sebagai dorongan seseorang untuk melakukan kebaikan

${ }^{5}$ Departemen Pendidikan Nasional, Kamus Besar Bahasa Indonesia "Pusat Bahasa", (Jakarta: PT. Insan Media Pustaka, 2008) h. 86.

"Sidi Gazalba, Masyarakat Islam "Pengantar Sosiologi dan Sosiografi", (Jakarta: Bulan Bintang, 1989), h. 5.

7Departemen Pendidikan Nasional, Kamus Besar Bahasa Indonesia "Pusat Bahasa", h. 86.

8Nugroho J. Setiadi, Perilaku Konsumen, (Jakarta: Kencana, 2003), h. 25. 
dalam memenuhi kebutuhan pribadi maupun manusia pada umumnya baik kebutuhan fisik, psikologis maupun sosial. ${ }^{9}$

\section{Tabungan}

Tradisi fiqh Islam, prinsip titipan atau simpanan (tabungan) dikenal dengan prinsip al-wadi'ah. Al-wadi'ah dapat diartikan sebagai titipan murni dari satu pihak ke pihak lain baik individu maupun badan hukum yang harus dijaga dan dikembalikan kapan saja penitip menghendaki. ${ }^{10}$

\section{Arisan}

Arisan merupakan sekelompok orang yang menyerahkan sejumlah uang kepada ketua arisan secara rutin atau berkala dengan jumlah uang yang sama, kemudian diundi untuk menentukan siapa yang mendapatkan arisan tersebut. ${ }^{11}$ Menurut kamus umum bahasa Indonesia, arisan adalah kegiatan mengumpulkan uang atau barang yang bernilai sama oleh beberapa orang kemudian diundi di antara mereka untuk menentukan siapa yang memperolehnya, undian dilaksanakan dalam sebuah pertemuan secara berkala sampai semua anggota memperolehnya. ${ }^{12}$ Adapun hukum arisan adalah sebagai berikut.

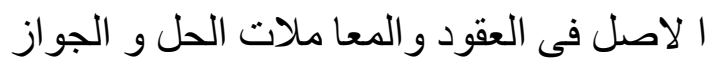

"pada dasarnya hukum transaksi dan muamalah itu adalah halal dan boleh".

${ }^{9}$ Ali Hasan, Manajemen Bisnis Syariah, (Yogyakarta: Pustaka Pelajar, 2009), h. 70

${ }^{10}$ Muhammad Syafi'I Antonio, Bank Syariah dari Teori ke Praktik, h. 85

${ }^{11}$ Ahmad Gozali, Cashflow for women menjadikan perempuan sebagai manager keuangan keluarga paling top, (Jakarta Selatan: Mizan Publika, 2005), h. 52

${ }^{12}$ Departemen Pendidikan Nasional, Kamus Besar Bahasa Indonesia "pusat bahasa", h. 86 


\section{Lelang (Jual Beli Muzayadah)}

Kitab-kitab fiqih atau hadist, jual beli lelang biasanya disebut dengan istilah bai'u al-muzayadah (adanya penambahan). Jual beli dalam istilah fiqih disebut al-bai'u yang berarti menjual, mengganti, dan menukar sesuatu dengan sesuatu yang lain. Sedangkan dalam bahasa Arab jual beli disebut al-bai'u yang berarti menukar. Kata al-bai'u dalam bahasa Arab terkadang digunakan untuk mengartikan lawannyayaitu asy-Syira (beli), dengan demikian al-bai'u berarti jual dan sekaligus bisa berarti beli. ${ }^{13}$ Menurut kamus besar bahasa Indonesia lelang adalah penjualan barang dihadapan banyak orang dengan tawarmenawar. Siapa yang tertinggi menawarnya dia berhak membeli barang tersebut. ${ }^{14}$

Dasar hukum lelang (jual beli muzayadah) seperti yang pernah dilakukan Rasulullah Saw dalam hadisnya dari Anas bin Malik:

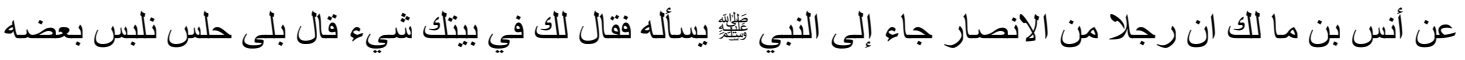

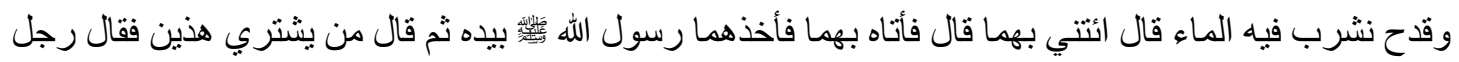

$$
\begin{aligned}
& \text { أنا آخذها بدر هم قال من يزيد على در هم مرنين أو ثناثا قال رجل أنا آخذهما بدر همين فأعطاهما إياه وأخذ } \\
& \text { الدر همين فأعطاهما الانصاري }
\end{aligned}
$$

Artinya:

Sesungguhnya seseorang laki-laki dari Ansar datang bertanya pada Rasulullah SAW. Maka Rasulullah berkata: Apakah di rumahmu ada sesuatu?, sahabat Ansar menjawab: Ya ada permadani, sebagian saya pakai dan sebagian saya hamparkan untuk tempat duduk dan mangkok yang saya pakai untuk minum. Nabi SAW berkata: bawa kemari keduanya, saya mengambil dengan satu dirham, kata seorang laki-laki. Kata Nabi: siapa yang berani menambah dua atau tiga kali lipat?,

13Srining Astutik, “Tinjauan Hokum Islam Terhadap Pelaksanaan Arisan Lelang (Studi Kasus Di Desa Sumberjo Kecamatan Rembang Kabupaten Rembang)", (15 Desember 2016 5: 37 AM) 806

14Departemen Pendidikan Nasional, Kamus Besar Bahasa Indonesia “pusat bahasa”, h. 
seorang laki-laki lainnya berkata: Saya berani membelinya dua dirham. (HR. Ibnu Majah). ${ }^{15}$

\section{Ekonomi Islam}

Ekonomi Islam menurut Umar Chapra adalah sebuah pengetahuan yang membantu upaya realisasi kebahagiaan manusia melalui alokasi dan distribusi sumber daya yang terbatas yang berada dalam koridor yang mengacu pada pengajaran Islam tanpa memberikan kebebasan individu atau tanpa perilaku makro ekonomi yang berkesinambungan dan tanpa ketidakseimbangan lingkungan. ${ }^{16}$ Ada beberapa prinsip yang harus diperhatikan dalam ekonomi Islam dalam melakukan transaksi, yaitu prinsip tauhid, prinsip nubuwwah, prinsip khilafah, prinsip keadilan, dan prinsip pertanggungjawaban.

Selain itu, ada beberapa hal yang harus dihindari dalam melakukan transaksi muamalah, yaitu sebagai berikut:

\section{Maisir}

Menurut bahasa maisir berarti gampang atau mudah. Menurut istilah maisir berarti memperoleh keuntungan tanpa harus bekerja keras. Maisir sering dikenal dengan perjudian karena dalam praktik perjudian seseorang dapat memperoleh keuntungan dengan cara mudah.

Gharar

Gharar dapat diartikan sebagai ketidakpastian atau ketidakjelasan (uncertainty). Unsur ini juga dilarang dalam Islam. Gharar atau disebut juga taghriir adalah sesuatu di mana terjadi incomplete information karena adanya uncertainty to both parties (ketidakpastian dari kedua belah pihak yang bertransaksi).

${ }^{15}$ Program I Hadis, Mausu'ah al-Hadith al Sharif.Kategori Sunan Ibnu Majah, Kitab alTijarat: No Hadis, 2189.

${ }^{16}$ Mustafa Edwin Nasution, Pengenalan Ekslusif Ekonomi Islam, h. 16. 
Riba

Riba secara bahasa bermakna ziyadah yang artinya tambahan. Dalam pengertian lain, secara linguistik riba juga berarti tumbuh dan membesar. Adapun menurut istilah, riba berarti pengambilan tambahan dari harta pokok atau modal secara batil. Riba secara umum adalah pengambilan tambahan baik dalam transaksi jual beli maupun pinjam meminjam secara batil atau bertentangan dengan prinsip muamalah dalam Islam. ${ }^{17}$

\section{METODOLOGI PENELITIAN}

Jenis penelitian yang digunakan dalam penelitian ini adalah penelitian kualitatif. Penelitian kualitatif adalah prosuder penelitian yang menghasilkan data deskriptif berupa kata-kata tertulis maupun lisan dari orang-orang atau perilaku yang diamati. ${ }^{18}$ Adapun jenis data yang digunakan dalam penelitian ini adalah jenis data primer. Sumber data penelitian ini akan diproleh langsung dari tempat penelitian dalam proses penelitian yang akan di lakukan peneliti pada lokasi penelitian yang telah dicantumkan. Adapun sumber data peneliti berasal dari ketua arisan, dan peserta arisan.

Metode pengumpulan data yang digunakan dalam penelitian ini adalah metode wawancara langsung kepada pihak yang akan di teliti yaitu pendiri arisan, dan beberapa peserta arisan. Adapun dalam penelitian ini, penulis akan menggunakan instrumen penelitian seperti, pedoman wawancara berupa beberapa pertanyaan-pertanyaan mengenai Pelaksanaan arisan lelang, observasi, alat perekam atau dokumentasi dan instrumen penelitian lainnya yang membantu dan mempermudah peneliti dalam melakukan analisis dan penyelesaian penelitian. Uji keabsahan dilakukan dengan menggunakan metode triangulasi yaitu triangulasi sumber data dan triangulasi teori.

\footnotetext{
17Muhammad Syafi'I Antonio, Bank Syariah dari Teori ke Praktik, h. 37

18Burhan Bungin, Penelitian Kualitatif (Cet ke-8; Jakarta, Kencana 2015), h. 68.
} 


\section{Motivasi Masyarakat Terhadap Pelaksanaan Arisan Lelang Di Desa Paomacang Kecamatan Sukamaju Kabupaten Luwu Utara}

Motivasi adalah aktivitas perilaku yang bekerja dalam usaha memenuhi kebutuhan-kebutuhan yang diinginkan.Motivasi dalam Islam diartikan sebagai dorongan seseorang untuk melakukan kebaikan dalam memenuhi kebutuhan pribadi maupun manusia pada umumnya baik kebutuhan fisik, psikologis maupun sosial. ${ }^{19}$

Berdasarkan wawancara dan observasi peneliti, adapun motivasi masyarakat ikut serta dalam pelaksanaan arisan lelang yaitu:

\section{Faktor Kemudahan dan Kebutuhan}

Arisan lelang menjadi hal yang mudah menurut masyarakat Desa Paomacang dalam hal menabung sebagai simpanan tetap ataupun berjaga-jaga. Selain itu, masyarakat memandang bahwa arisan lelang ini memiliki sisi positif baik dari sisi ekonomi maupun sosial, seperti yang dikatakan oleh Latang yang berlatar belakang sebagai petani:

"Motivasi saya ikut serta dalam arisan lelang adalah menabung sebagai simpanan dan berjaga-jaga untuk memenuhi kebutuhan hidup yang bernilai jangka panjang ataupun kebutuhan yang mendesak lainnya seperti tagihan utang yang harus dilunasi, kebutuhan untuk berobat, dan biaya pendidikan yang harus dipersiapkan untuk anak agar supaya masa depannya bisa lebih baik dari kami yang hanya berprofesi sebagai petani" ${ }^{20}$

Berdasarkan pemaparan yang dikatakan oleh pelaku arisan lelang masyarakat Desa Paomacang Kecamatan Sukamaju Kabupaten Luwu Utara yang berlatar belakang pedagang dan petani tergolong masyarakat ekonomi menengah dapat menjadikan arisan lelang sebagai salah satu cara untuk menabung dalam jumlah skala standar.

${ }^{19}$ Ali Hasan, Manajemen Bisnis Syariah, h. 70

20 Wawancara dengan Latang,"Peserta Arisan" Tanggal 25 Desember 2017 di Desa Paomacang Kecamatan Sukamaju Kabupaten Luwu Utara 


\section{Faktor Ekonomi dan Pendidikan}

Zaman serba modern saat ini sumber daya manusia di tuntut untuk lebih berpengetahuan dan maju demi mengimbangi zaman yang semakin berkembang maka kualitas diri juga harus berkembang pula.Khusus untuk masyarakat Desa Paomacang Kecamatan Sukamaju Kabupaten Luwu Utara untuk menambah wawasan dan pengetahuan salah satu metode yang digunakan adalah bersekolah.

Meskipun telah banyak kemudahan yang ada masih ada orang tua yang tidak menyekolahkan anaknya alasan terbesar adalah ekonomi yang semakin meningkat. Sehingga para orang tua terpaksa membiarkan anaknya tidak sekolah karena takut akan biaya sekolah yang semakin mahal, bagi orang tua yang mempunyai kemampuan finansial yang cukup bisa saja menyekolahkan anaknya di sekolah yang berkualitas baik dan juga mahal bahkan hingga keperguruan tinggi. Namun bagaimana dengan mereka yang mempunyai ekonomi lemah? Salah satu masyarakat Desa Paomacang Kecamatan Sukamaju Kabupaten Luwu Utara oleh Jamalu yang berlatar belakang sebagai buruh tani mengatakan bahwa:

"Pendapatan saya hanya berasal dari buruh tani untuk semua kebutuhan keluarga dan anak saya sangat berantusias untuk melanjutkan pendidikan yang lebih tinggi untuk mencapai cita-citanya sebagai guru.Sehingga saya harus bekerja lebih giat untuk mewujudkan cita-cita anak saya, karena sayapun sangat mendorong anak saya untuk bersekolah setingi-tingginya agar supaya nasibnya tidak seperti saya.Karena itu saya ikut arisan lelang sebagai bentuk tabungan untuk anak saya, biasanya saya menitipkan sebagian gaji hasil buruh saya kepada ketua arisan sampai pembayaran saya genap atau bisa disebut saya bayarnya cicil untuk satu kali putaran". ${ }^{21}$

Berdasarkan pemaparan pelaku arisan lelang di Desa Paomacang Kecamatan Sukamaju Kabupaten Luwu Utara walaupun ekonomi rendah tapi pendidikan harus tinggi.Oleh karena itu, masyarakat yang bekerja sebagai buruh tani melakukan arisan lelang untuk menabung sebagian hasil kerjanya

${ }^{21}$ Wawancara dengan Jamalu, "Peserta Arisan" Tanggal 26 Desember 2017 di Desa Paomacang Kecamatan Sukamaju Kabupaten Luwu Utara 
yang di sisipkan kepada ketua arisan untuk tambahan keperluan pendidikan anaknya.

\section{Mekanisme Pelaksanaan Arisan Lelang}

Kegiatan arisan dilakukan dengan adanya pengumpulan dana sesuai dengan kesepakatan berdasarkan waktu yang telah ditetapkan dan dilakukan pemilihan setiap periodenya untuk menentukan pemenang arisan. Hal ini dilakukan secara terus-menerus secara bergiliran hingga seluruh peserta arisan memperoleh bagiannya masing-masing. Hasil yang didapatkan peserta arisan biasanya berupa uang, selain itu ada juga yang berupa barang seperti alat-alat rumah tangga dan sebagainya.Hal ini tergantung kesepakatan antara peserta dan ketua arisan.

Arisan uang dengan sistem lelang atau biasa disebut arisan lelang di Desa Paomacang Kecamatan Sukamaju Kabupaten Luwu Utara merupakan salah satu bentuk muamalah yang sudah ada sejak tahun 2005 dan berkembang hingga sekarang. Salah satu indikator perkembangannya dapat di lihat dari segi peserta yang semakin meningkat dan jumlah kelompok arisan yang semakin banyak di desa tersebut.Hal ini dapat disimpulkan bahwa kegiatan ini sangat diminati oleh masyarakat setempat dan menjadi aktivitas yang berlangsung secara turun-temurun.

Salah satu arisan lelang yang terdapat di Desa Paomacang ini awal berdirinya hanyalah berbentuk arisan biasa yang pemilihan pemenangnya menggunakan lot.Setelah beberapa tahun barulah arisan ini berkembang menjadi arisan lelang atas rekomendasi para anggota yang ikut serta dalam arisan tersebut. Hal ini berarti para peserta memiliki rasa kepercayaan yang tinggi terhadap pengelola arisan untuk mengembangkan kegiatannya ke tahap yang lebih sulit karena tidak lagi menggunakan lot untuk menentukan 
pemenangnya melainkan dengan sistem lelang yang resikonya siap rugi demi mendapatkan arisan lebih cepat. ${ }^{22}$

Kesepakatan yang dilakukan di dalam arisan ini juga dilakukan secara lisan yang dilandasi dengan adanya kepercayaan di antara masing-masing peserta arisan.Kepercayaan ini diperoleh dengan adanya pengetahuan masingmasing peserta terhadap karakteristik, sifat, dan kemampuan ekonomi para peserta lainnya.Tahap penyeleksian terhadap calon peserta arisan lelang ini dilakukan oleh ketua arisan yang telah memegang kendali kegiatan tersebut karena ketua arisan telah mengetahui seluk beluk kehidupan para anggotanya sehingga tidak ada keraguan untuk mengikuti kegiatan arisan lelang tersebut. ${ }^{23}$

Peserta arisan yang ikut serta dalam kegiatan tersebut bervariasi, tidak hanya diikuti oleh kaum ibu-ibu saja, akan tetapi kaum bapak-bapak, bahkan ada juga peserta yang masih remaja ikut andil dalam kelompok arisan lelang tersebut. Hal ini disebabkan sebagian besar peserta arisan memiliki kebutuhan untuk membiayai pendidikan anak, dan khusus remaja untuk tambahan "uang panai" ujarnya. ${ }^{24}$ Inilah yang menjadi motivasi atau alasan peserta mengikuti arisan uang dengan sistem lelang dikarenakan apabila dalam keadaan terdesak peserta dapat melakukan lelang setinggi-tingginya untuk memenangkan arisan secara cepat.

Jumlah peserta arisan lelang yang ada di Desa Paomacang sebanyak 23 orang dengan jumlah lot sebanyak 31. Sebagian peserta arisan mengambil 2-3 lot selama peserta tersebut masih bisa menanggung biaya iuran setiap bulannya yang telah disepakati bersama.Arisan lelang ini berlangsung selama 31 bulan (2 tahun 7 bulan) sesuai jumlah lot arisan dengan jumlah iuran sebesar Rp. 200.000 setiap lot. Sehingga total hadiah yang didapatkan sebesar Rp.6.200.000 setiap

\footnotetext{
22 Wawancara dengan Suni "Ketua Arisan", Tanggal 25 Desember 2017 di Desa Paomacang Kecamatan Sukamaju Kabupaten Luwu Utara

${ }^{23}$ Wawancara dengan Hj. Mini "Peserta Arisan", Tanggal 26 Desember 2017 di Desa Paomacang Kecamatan Sukamaju Kabupaten Luwu Utara

${ }^{24}$ Wawancara dengan Suni "Ketua Arisan", Tanggal 25 Desember 2017 di Desa Paomacang Kecamatan Sukamaju Kabupaten Luwu Utara
} 
putarannya yang dilaksanakan pada tanggal 25 pukul 12.00 apabila penentuannya tidak menggunakan sistem lelang. ${ }^{25}$

Apabila dalam penentuan arisan dilakukan dengan cara lelang maka total hadiah yang diterima tidak full Rp 6.200.000 karena adanya potongan harga lelang yang diajukan peserta pemenang arisan. Jadi, harga lelang dalam arisan ini dijadikan sebagai tingkat kerugian para peserta arisan demi memenangkan arisan secara cepat. Lelang mulai dilakukan pada putaran kedua karena pemenang arisan yang pertama adalah pemilik atau pengelola arisan itu sendiri yang sudah menjadi kesepakatan bersama begitupun untuk peserta terakhir yang memenangkan arisan, sistem lelang tidak lagi dilakukan sehingga total uang yang di terima juga tetap pada jumlah yang semestinya. ${ }^{26}$

Sebagaimana yang telah dilakukan para peserta arisan di Desa Paomacang Kecamatan Sukamaju Kabupaten Luwu Utara pada tanggal 25 Desember 2017 yang lalu tepat pada putaran ke 6 (enam) sebanyak 6 orang dari 17 peserta wajib lelang dengan lot atas nama Renaldi (Rp 2.155.100), Andi (Rp 1.915.000), Latang (Rp 1.950.000), Martang (Rp 10.000), Apra (Rp 700.000), dan Imel (Rp 100.000). Maka yang menjadi pemenang lelang adalah atas nama Renaldi dengan harga lelangan sebesar Rp 2.155.100 dan total jumlah uang yang diterima sebesar Rp 4.044.900 dari (Rp 6.200.000 - Rp 2.155.100).

Asumsi tersebut, setiap anggota membayarkan uang iuran seperti biasanya tetapi uang iuran tidak lagi Rp 200.000 karena jumlah uang yang diperoleh pemenang arisan sebesar Rp 4.044.900 setelah dikurangi dengan harga lelang sehingga para anggota lainnya mengumpulkan iuran masingmasing hanya sebesar Rp 130.480 saja. Sedangkan pemenang arisan dapat mengambil uang hasil lelangannya 3 hari setelah pengundian sesuai dengan kesepakatan bersama, waktu tersebut digunakan ketua arisan untuk mengumpulkan iuran para peserta yang belum membayar.Kecuali pemenang

${ }^{25}$ Wawancara dengan Hj. Mini "Peserta Arisan", Tanggal 26 Desember 2017 di Desa Paomacang Kecamatan Sukamaju Kabupaten Luwu Utara

${ }^{26}$ Wawancara dengan Hj. Mini "Peserta Arisan", Tanggal 26 Desember 2017 di Desa Paomacang Kecamatan Sukamaju Kabupaten Luwu Utara 
arisan sangat membutuhkan uang tersebut pada hari itu juga maka ketua arisan yang bertanggung jawab menanggung semua iuran para peserta yang belum membayar.

Lelangan biasanya dilakukan oleh para peserta yang sangat membutuhkan. Dalam hal ini, setiap peserta memiliki kebebasan untuk melelang ataupun tidak.jumlah atau nominal lelangan juga tidak dibatasi minimal dan maksimalnya. Sehingga para peserta tidak merasa terbebani mengenai jumlah atau nominal lelangan yang akan diberikan. Selanjutnya, lelangan dilakukan dengan cara menuliskan nominal lelangan di selembar kertas. Kemudian, kertas tersebut diserahkan kepada ketua arisan untuk menyeleksi peserta yang dapat memenangkan arisan tersebut berdasarkan nilai nominal lelangan yang tertinggi. Hal ini akan dilakukan secara berulang-ulang hingga seluruh peserta memenangkan arisannya masing-masing.

\section{Pandangan Ekonomi Islam Terhadap Pelaksanaan Arisan Lelang}

Pada dasarnya setiap muamalah yang dilakukan hukumnya adalah mubah atau boleh sampai ada dalil yang mengharamkannya.Begitu juga dengan hukum arisan di dalam Islam adalah mubah (boleh) apabila dalam melakukan transaksi muamalah tidak mengandung unsur-unsur maisir, gharar, dan riba.Selain itu, transaksi muamalah juga harus berjalan sesuai dengan prinsip dasar ekonomi Islam yaitu prinsip tauhid, prinsip nubuwwah, prinsip khilafah, prinsip keadilan, dan prinsip pertanggung jawaban.

Berdasarkan arisan uang dengan sistem tawaran atau lelang yang berlaku di Desa Paomacang Kecamatan Sukamaju Kabupaten Luwu Utara, terdapat adanya ketidakseimbangan antara jumlah iuran arisan yang disetorkan dengan jumlah yang diterima dan perbedaan total uang yang didapatkan masing-masing peserta setiap putarannya. Meskipun sistem lelang dilakukan untuk menolong peserta yang sangat membutuhkan agar mendapatkan arisan secara cepat namun Allah sangat membenci bahkan melaknat orang-orang yang melakukan tolong menolong dalam bentuk 
keburukan yang didalamnya mengandung unsur menzalimi orang lain. Sebagaimana firman Allah dalam QS. Al-Maidah/5:2.

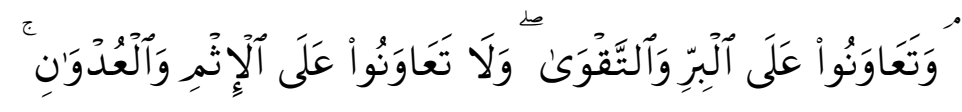

Terjemahnya:

Dan tolong menolonglah kamu dalam (mengerjakan) kebaikan dan takwa, dan janganlah kamu tolong menolong dalam berbuat dosa dan pelanggaran.

Dalam QS. AL-Maidah/5:2 menjelaskan bahwa Allah melarang umatnya melakukan tolong menolong dalam berbuat dosa dan pelanggaran karena merupakan hal yang merugikan untuk orang lain atau bisa dikatakan adanya unsur menzalimi orang lain dengan itu ayat di atas menekankan bahwa Allah hanya menganjurkan umatnya melakukan kegiatan tolong menolong dalam hal yang baik-baik.

Riba secara umum adalah pengambilan tambahan baik dalam transaksi jual beli maupun pinjam meminjam secara batil atau bertentangan dengan prinsip muamalah dalam Islam. ${ }^{27}$ Riba merupakan perbuatan orang-orang jahiliyah dan dapat menyengsarakan orang lain, dengan adanya riba orang menjadi malas berusaha yang sah menurut syara' dan menyebabkan putusnya perbuatan baik terhadap sesama manusia dengan cara menghilangkan faedah dalam melakukan transaksi muamalah dan secara tegas telah disebutkan pengharamannya di dalam Al-Qur'an dan Hadits.

Sebagaimana hadis yang telah dijelaskan Rasulullah, bahwa:

عن جابر قال لعن رسول الله صلى الله علده وسلم اكل الرباومؤكله وكاتبه وشا هدنه وقال هم سو اء (رو اه مسلم)

Artinya:

“Dari Jabir, ia berkata: Rasulullah SAW mengutuk orang yang memakan riba, orang yang mewakilinya, orang yang mencatatnya, dan dua orang

27Muhammad Syafi'I Antonio, Bank Syariah dari Teori ke Praktik, h. 37 
yang menjadi saksinya. Nabi bersabda, mereka itu sama (dosanya)". HR. Muslim $^{28}$

Hadis Nabi yang diriwayatkan oleh Jabir menjelaskan bahwa orang yang melakukan riba, baik yang memberi, menerima, dan yang menjadi saksi kegiatan tersebut dalam perspektif hadis Nabi sama dosanya.Keterkaitannya dengan kegiatan arisan uang dengan sistem lelang yang dalam mekanisme pelaksanaannya terdapat unsur-unsur riba, berdasarkan hadis Nabi maka kegiatan arisan lelang tersebut menjadi salah satu kegiatan yang bertentangan dengan prinsip dasar dalam bermuamalat.

Unsur riba dalam praktik arisan uang dengan sistem tawaran atau lelang terletakpada pengurangan jumlah iuran yang diterima para peserta setiap periodenya akibat dari harga tawaran atau lelangan yang diberikan oleh pemenang arisan. Sebagaimana hadis Nabi yang diriwayatkan oleh Jabir yang menjadi pemberi riba adalah peserta yang memenangkan arisan dengan lelangan tertinggi, dan yang menjadi penerima serta saksi riba adalah peserta lain yang mendapatkan potongan iuran tersebut.

Maisir sering dikenal dengan perjudian karena dalam praktik perjudian seseorang dapat memperoleh keuntungan dengan cara mudah tanpa harus bekerja keras.Sebagaimana Allah Swt memberi penegasan terhadap keharaman melakukan aktivitas ekonomi yang mengandung unsur maisir (perjudian) dalam QS. Al-Maidah/5:90.

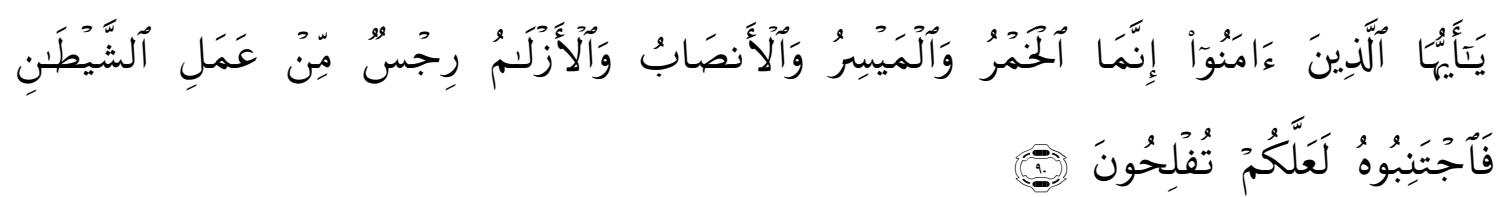

Terjemahnya:

Hai orang-orang yang beriman, sesungguhnya meminum khamar, berjudi, berkorban untuk berhala, mengundi nasib dengan panah, adalah

28Idri, Hadis Ekonomi "Ekonomi Dalam Perspektif Hadis Nabi", h. 188 
perbuatan keji termasuk perbuatan setan.Maka jauhilah perbuatanperbuatan itu agar kamu mendapat keberuntungan. ${ }^{29}$

Ayat al-Qur'an tersebut menjelaskan bahwa segala bentuk perbuatan yang merugikan seperti meminum khamar, berjudi, dan memuja berhala merupakan perbuatan setan. Allah Swt. memerintahkan kepada umatnya untuk menjauhi segala yang dilarang-Nya agar mendapat keberuntungan.Keterkaitannya dengan kegiatan arisan uang dengan sistem lelang yang dalam mekanisme pelaksanaannya terdapat unsur maisir.Unsur maisir dalam kegiatan arisan lelang terletak pada sistem pelaksanaanya, yaitu dengan adanya praktik lelang atau tawaran harga yang dilakukan para peserta arisan setiap periodenya dalam menentukan pemenang arisan.

Gharar dapat diartikan sebagai ketidakpastian atau ketidakjelasan dalam bertransaksi. Sebagaimana dalam al-Qur'an tidak ada nash secara khusus yang mengatakan hukum gharar akan tetapi secara umum dapat dimasukkan dalam QS. Al-Baqarah/2:188

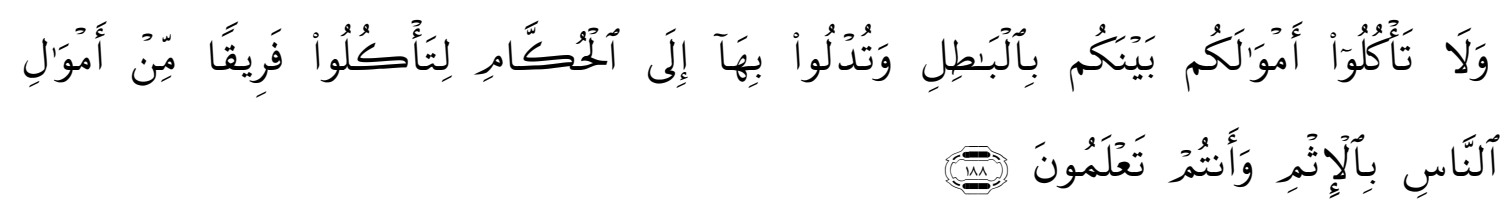

Terjemahnya:

Dan janganlah sebagian kamu memakan harta sebagian dari yang lain diantara kamu dengan jalan yang batil dan (janganlah) kamu membawa (urusan) harta itu kepada hakim, supaya kamu dapat memakan sebahagian daripada harta benda orang lain itu dengan (jalan berbuat) dosa, padahal kamu mengetahui. ${ }^{30}$

Berdasarkan QS. Al-Baqarah ayat ke 188 menjelaskan bahwa dalam mencari nafkah haruslah dengan cara yang halal dan di ridhoi Allah SWT agar

\footnotetext{
${ }^{29}$ Departemen Agama, Al-Qur'an dan Terjemahannya, h. 106

30 Departemen Agama, Al-Qur'an dan Terjemahannya, h. 29
} 
rezeki yang kita dapatkan berkah, tidak dengan melakukan kecurangan atau hal-hal yang dilarang agama dan undang-undang demi mendapatkan rezeki yang melimpah.

Keterkaitannya dengan kegiatan arisan uang dengan sistem lelang yang dalam mekanisme pelaksanaannya terdapat unsur gharar. Unsur gharar dalam kegiatan arisan lelang terletak pada jumlah iuran dan total uang undian yang didapatkan para peserta berbeda-beda karena adanya pengurangan dari harga lelang tersebut. Sehingga pada periode kedepannya para peserta tidak mengetahui berapa total uang yang akan didapatkan pemenang arisan karena adanya ketidakjelasan jumlah iuran yang harus di bayar tiap peserta dan total uang yang didapatkan sangat dipengaruhi oleh jumlah iuran peserta.

\section{KESIMPULAN}

Berdasarkan penelitian yang telah dilakukan di Desa Paomacang Kecamatan Sukamaju Kabupaten Luwu Utara serta hasil yang diperoleh seperti yang telah dijelaskan pada bab-bab sebelumnya, dapat ditarik kesimpulan bahwa Motivasi masyarakat ikut serta dalam kegiatan arisan lelang di Desa Paomacang Kecamatan Sukamaju Kabupaten Luwu Utara yaitu diberlakukannya sistem tawaran atau lelang, sehingga para peserta yang sangat membutuhkan dapat melakukan tawaran dengan nominal yang besar agar dapat memenangkan arisan secara cepat. Selain itu, karena faktor kemudahan dalam menabung. Masyarakat lebih memilih untuk menyimpan sebagian hasil pendapatannya dengan ikut serta dalam arisan lelang daripada menabung di bank karena banyaknya prosedur yang harus diikuti sedangkan di Desa Paomacang sebagian masyarakatnya masih awam dan juga jarak antara bank dengan Desa Paomacang yang menjadi kendala masyarakat. Pelaksanaan arisan lelang yang dilakukan sebagian masyarakat Desa Paomacang Kecamatan Sukamaju ditinjau dari pandangan ekonomi Islam yaitu adanya ketidakadilan 
dan menzalimi peserta arisan walaupun ada unsur kesepakatan yang telah dibuat sebelumnya. Selain itu, arisan lelang juga terdapat unsur-unsur yang dilarang dalam melakukan transaksi muamalah yaitu adanya unsur riba, gharar, dan maisir dalam praktik pelaksanaannya. Oleh karena itu, arisan uang dengan sistem lelang terdapat unsur-unsur yang tidak sesuai dalam pandangan ekonomi Islam.

\section{DAFTAR PUSTAKA}

Abdurrahman, Masduha. Pengantar dan Asas-asas Hukum Perdata Islam "Figh Muamalah". Surabaya: Central Media. 1992

Antonio, Muhammad Syafi'i. Bank Syariah dari Teori ke Praktik. Jakarta: Gema Insani. 2001.

Astutik, Strining. Tinjauan Hukum Ekonomi Islam Terhadap Pelaksanaan Arisan Lelang (Studi Kasus di Desa Sumberjo Kecamatan Rembang Kabupaten Rembang), Jurnal Ilmiah.

Bungin, Burhan. Penelitian Kualitatif. Jakarta: Kencana. 2009.

Departemen Agama. Al-Qur'an dan Terjemahannya, Jakarta: PT. Insan Media Pustaka. 2013.

Departemen Pendidikan Nasional. Kamus Besar Bahasa Indonesia "pusat bahasa", cet. 4. Jakarta: 2008.

Gazalba, Sidi. Masyarakat Islam "Pengantar Sosiologi dan Sosiografi". Jakarta: Bulan Bintang. 1989.

Gozali, Ahmad. Cashflow for mowen menjadikan perempuan sebagai manager keuangan keluarga paling top. Jakarta Selatan: Mizan Publika. 2005.

Hasan, Ali. Manajemen Bisnis Syariah. Yogyakarta: Pustaka Pelajar. 2009.

Hj. Mini. Peserta Arisan. Paomacang: wawancara. 2017

Idri. Hadis Ekonomi "Ekonomi dalam Perspektif Hadis Nabi". Jakarta: Kencana. 2015

Jamalu. Peserta Arisan. Paomacang: wawancara. 2017

Latang. Peserta Arisan. Paomacang: wawancara. 2017

Muhammad. Lembaga-Lembaga Keuangan Umat Kontemporer. Yogyakarta: UII Press. 2000. 